\title{
Polyspecific antibodies without persisting antigen in multiple sclerosis, neurolupus and Guillain-Barré syndrome: immune network connectivity in chronic diseases
}

Anticorpos poliespecíficos sem antígeno persistente em esclerose múltipla, neurolupus e síndrome de Guillain-Barré: conectividade imunológica em doenças crônicas

Hansotto Reiber ${ }^{1}$

\begin{abstract}
The polyspecific antibody synthesis in multiple sclerosis (MS) gained diagnostic relevance with the frequent combination of measles-, rubella- and varicella zoster antibodies (MRZ-antibody reaction) but their pathophysiological role remains unknown. This review connects the data for intrathecal polyspecific antibody synthesis in MS and neurolupus with observations in the blood of patients with Guillain-Barré syndrome (GBS). Simultaneously increased antibody and autoantibody titers in GBS blood samples indicate that the polyspecific antibodies are based on a general property of an immune network, supported by the deterministic day-to-day concentration variation of antibodies in normal blood. Strongly correlated measles- and rubella- antibody variations point to a particular connectivity between the MRZ antibodies. The immune network, which provides serological memory in the absence of an antigen, implements the continuous change of the MRZ pattern in blood, not followed by the earlier immigrated B cells without corresponding connectivity in the brain. This may explain the different antibody patterns in cerebrospinal fluid, aqueous humor and blood of the individual MS patient. A complexity approach must implement a different view on causation in chronic diseases and causal therapies.
\end{abstract}

Keywords: cerebrospinal fluid; autoimmune diseases; antibodies; M,R,Z-antibody reaction; multiple sclerosis; Guillain-Barré syndrome, neurolupus.

\section{RESUMO}

A síntese de anticorpos poliespecíficos em esclerose múltipla (EM) ganhou relevância diagnóstica com a combinação frequente de anticorpos contra sarampo, rubéola e varicela-zoster (reação de anticorpos MRZ), mas seu papel fisiopatológico permanece desconhecido. Esta revisão relaciona os dados da síntese intratecal de anticorpos poliespecíficos em EM e Neurolupus com observações no sangue de pacientes com síndrome de Guillain Barré (SGB). Simultaneamente, os títulos aumentados de anticorpos e autoanticorpos em amostras de sangue de SGB indicam que os anticorpos poliespecíficos se baseiam numa propriedade geral de uma rede imunitária, suportada pela variação determinística da concentração diária de anticorpos no sangue normal. As variações fortemente correlacionadas de anticorpos contra sarampo e rubéola apontam para uma conectividade particular entre os anticorpos MRZ. A rede imunitária, que fornece memória sorológica na ausência de um antígeno, implementa a mudança contínua do padrão MRZ no sangue, não seguida pelas células B que imigraram anteriormente sem conectividade no cérebro. Isto pode explicar os diferentes padrões de anticorpos no LCR, humor aquoso e sangue do paciente individual de EM. Uma abordagem complexa deve implementar uma visão diferente sobre a causalidade em doenças crônicas e terapias causais.

Palavras-chave: líquido cefalorraquidiano; doenças autoimunes; anticorpos; reação de anticorpos MRZ; esclerose múltipla; síndrome de Guillain Barré, neurolupus.

The polyspecific antibody synthesis in the brain of multiple sclerosis (MS) patients ${ }^{1}$ was, and still is, a permanent motivation to search for a causative antigen. But, as shown in a meta analysis ${ }^{2}$, in 60 years of research with 5,800 epitopes investigated, no causative function could unambiguously be identified for autoimmune diseases or multiple sclerosis. There is still poor acceptance of an antibody synthesis in the absence of a B cell activating antigen in the brain ${ }^{1}$. Another irritation in the research of chronic diseases comes from a clear statistical correlation between infections and autoimmune diseases, 
including $\mathrm{MS}^{3}$. This connection is supported by the association of vaccinations with a three-week to two-month delayed appearance of multi-symptom diseases, like Gulf war illness, chronic fatigue or Guillain-Barré syndrome ${ }^{4,5,6}$.

This shows that there is a basic deficit in the understanding of the causation of chronic diseases; in fact, of the nature of chronic disease at all ${ }^{4}$.

It is the intention of this review to provide a closer look at the characteristics of the polyspecific antibody response and its role in the pathological process. For this purpose, this article reviews the knowledge about polyspecific antibodies in autoimmune diseases with involvement of the $\mathrm{CNS}^{7}$, as well as the polyspecific antibody pattern with an individual connectivity in the blood of patients with a Guillain-Barré syndrome (GBS) ${ }^{8}$, as an extension to the better-characterized reactions in $\mathrm{MS}^{1,9,10,11}$.

In particular, the correlations between the day-to-day variations of individual antibody concentrations shown in the blood of controls may help to get a better acceptance for the connectivity between antibodies as a general property of an immune network ${ }^{12}$.

\section{MULTIPLE SCLEROSIS}

The basic knowledge about the polyspecific antibodies comes from the sensitive detection and interpretation of the specific Antibody Index as a relative value ${ }^{11}$ and the quantitative specific fraction, Fs, the amount of the intrathecally-synthesized antibody species as a fraction of the amount of the total intrathecally-synthesized $\operatorname{IgG}^{13,14}$. The individual antibody species can also be shown as part of the oligoclonal bands in cerebrospinal fluid (CSF $)^{15}$.

The measles-, rubella-, varicella zoster- antibodies have a much higher frequency compared to the other antibody species analyzed $^{11}$. The combined analysis, the so-called MRZ antibody reaction ${ }^{9}$, is the most sensitive measure for the detection of a polyspecific antibody synthesis, and this gained diagnostic relevance for detection of a chronic inflammatory process in the brain ${ }^{10,16,17,18,19}$. The MRZ antibody reaction is typical in chronic diseases, but missing in acute inflammatory diseases. Table 1 shows that a typical MRZ reaction with a combination of $\geq 2$ antibodies $(\mathrm{AB})$ was found in $28 / 29 \mathrm{MS}$ patients but not in any $(0 / 125)$ of the bacterial or viral neurological diseases investigated. Only a sporadic single antibody species of M, R or Z was detectable in a small fraction (10/125) of the acute inflammatory diseases (1 AB in Table1). Diagnosis of neurotuberculosis and neuroborreliosis fulfilled the criteria published ${ }^{10,11}$. Data of bacterial meningitis, general viral infections and HSV/VZV encephalitis were analysed and compiled by M. Albrecht in the Neurochemistry laboratory, University Goettingen.

But, in spite of the absence of a polyspecific MRZ reaction, the amount of the disease-specific antibodies in the acute inflammatory diseases remain still a minor fraction with a mean of $10-20 \%$ of total intrathecal IgG in acute or antigen-driven immune reactions ${ }^{13,14,20}$.

A theoretically important observation was the correlation of an increased frequency and an increased amount of MRZ antibodies at a larger intrathecal total IgG concentration ${ }^{9}$. As shown in Figure 1, the mean number of combined antibody species $(n=0-3)$ is higher in a larger amount of intrathecal total $\operatorname{IgG}\left(\operatorname{IgG}_{\mathrm{loc}}\right.$ in $\left.\mathrm{mg} / \mathrm{l}\right)$, i.e., the probability of finding all three MRZ antibodies synthesized in CNS increases with the amount of intrathecal total IgG, asymptotically approaching the maximal value $n=3^{9}$.

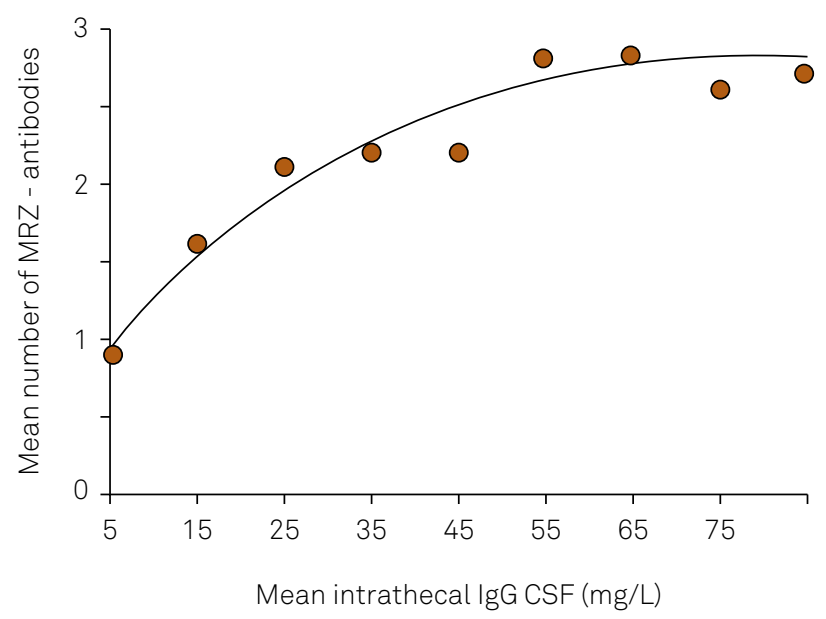

Figure 1. Mean frequency of antibody combinations in the MRZ reaction of MS patients with one $\left(n_{1}\right)$, two $\left(n_{2}\right)$ or three $\left(n_{3}\right)$ different antibody species (M, R and/or Z) in correlation with increasing amounts of intrathecal total IgG synthesis ${ }^{9}$. The mean amount of intrathecal total IgG in each interval with 20 patients was calculated with reference to a Qmean as IgGloc(mean) in $\mathrm{mg} / \mathrm{l} \mathrm{CSF}{ }^{8}$ with the CSF statistics program of www.albaum.it. The mean number of combined antibodies in each interval was calculated with $\left(n_{1}+2 n_{2}+3 n_{3}\right) / n$. ( $n=$ number of patients with one $\left(n_{1}\right)$, two $\left(n_{2}\right)$ or three $\left(n_{3}\right)$ antibodies in CSF).

Table 1. Frequency of intrathecal measles, rubella and /or varicella zoster antibodies (MRZ reaction) in various acute inflammatory diseases compared with Multiple sclerosis (MS). Results are counted as either only one of the M,R or Z antibodies (1 AB) or $\geq 2$ AB as combination of any 2 or 3 of the MRZ antibodies.

\begin{tabular}{|c|c|c|c|c|c|c|}
\hline Variable & Neuro-tubercul. & Neuroborrel. & Bact.Mening & Viral Infect. & HSV -Encephal. & MS \\
\hline N & 16 & 17 & 31 & 31 & 30 & 29 \\
\hline OCB pos & 7 & 15 & 11 & 8 & $9 * *$ & 29 \\
\hline $1 \mathrm{AB}$ pos & 3 & 3 & 1 & 1 & 1 & 1 \\
\hline$\geq 2 \mathrm{AB}$ pos & 0 & 0 * & 0 & 0 & 0 & 28 \\
\hline
\end{tabular}

OCB: oligoclonal bands; $\mathrm{AB}$ pos: antibody Index, $\mathrm{Al} \geq 1.5$; ${ }^{\star}$ one case in a later course of the disease; ${ }^{\star}$ Delayed appearance $(>14 \mathrm{~d}$ after start of disease) 
The total amount of intrathecal IgG cannot be interpreted as it depends on the nearness of the perivascular lymphocyte cuffs to the CSF space, which must be in reach for the diffusion process ${ }^{11}$.

This view of a mere statistical combination, then a specificity-dependent migration of $\mathrm{B}$ cells into the brain, was supported by the different local antibody patterns in the brain and in the eye of the individual MS patient ${ }^{1}$, which shows that the immigrating $B$ cell clones in the brain have local, arbitrarily different, antibody specificities ${ }^{1}$.

From further investigations, the following was also learned:

In a virus-driven immune response, the mean specific antibody concentration is 20-60-fold stronger compared with polyspecific antibodies of the same specificity ${ }^{13,14,20}$.

The polyspecifc antibodies in MS are based on the precondition of a wild type infection or vaccination, but not on any mimicking antigens ${ }^{1,21}$. The intrathecal synthesis of autoantibodies against $\mathrm{dsDNA}^{7}$ with a frequency of $19 \%$ is comparable to the average of other antibodies ${ }^{11}$. The high affinity of polyspecific antibodies in the $\mathrm{CSF}^{22,23}$, in contradiction to an earlier biased report ${ }^{24}$, is an important argument that the immigrating B cells are affinity-maturated in the lymph system and not in the brain ${ }^{1}$.

The polyspecific antibodies have, in general, a long-lasting stable concentration in the $\mathrm{CSF}^{25}$, different from the exponential decay of antibody concentrations in acute inflammatory diseases ${ }^{26}$.

Neither the amount of the MRZ antibodies in blood, nor their ranked sequence (blood pattern), correlates with the MRZ pattern in the $\mathrm{CSF}^{13}$. This observation is consistent with the locally different patterns in the brain and eye ${ }^{1}$. These observations led to the discussion of the natural dynamics of antibody concentrations in blood. (See below).

\section{AUTOIMMUNE DISEASES WITH INVOLVEMENT OF THE CNS}

An important extension of knowledge is that the polyspecific antibody response is detectable in autoimmune diseases with involvement of the brain ${ }^{7}$, like neurolupus, Sjögren syndrome and Wegener's granulomatosis or neurosarcoidosis.

The IgG patterns, with the associated blood-CSF barrier functions of neurolupus patients, are shown in an IgG Reibergram in Figure 2 and their corresponding MRZ-antibody combinations are presented in Table $2^{7}$; $6 / 10$ patients had an intrathecal antibody synthesis for one to four of the five antibody species investigated: Patient 3 has, together with the large intrathecal total IgG concentration, 4/5 analysed antibodies with an $\mathrm{AI}>1.5 .50 \%$ above the mean of the lower AI values in CSF of patient 4, the HSV- AI = 1.4 is also calculated as a synthesis, as the value is $50 \%$ above the lowest other $\mathrm{AI}=0.8$. But in case of a HSV $+\mathrm{VZV}$ combination the careful exclusion of a herpes encephalitis is important, to avoid a wrong interpretation. The intrathecal ds-DNA autoantibody synthesis (2/10, patients 3 and 9) had to be counted, albeit cases with a neurolupus, as part of a polyspecific immune response, seen at a similar frequency in the MS patients $(19 \%)^{11}$. This antibody evaluation, with the corrected Antibody Index ${ }^{11}$, was still more sensitive $(6 / 10)$ than by the detection of oligoclonal $\operatorname{IgG}^{11}$ (3/10 type 2$)$ or with the quotient diagram (3/10) (Figure 2) $)^{27}$.

Four of 10 patients had a slightly increased QAlb, i.e., a decreased CSF flow rate ${ }^{28}$. This is a typical pattern found in chronic diseases with a limited frequency and low amount of pathologically increased QAlb. As explained ${ }^{11,28,29}$, this reduced CSF turnover can be the consequence of a reduced elimination, but also of a reduced CSF production rate in the choroid plexus (Table 2).

\section{Polyspecific antibodies in blood - Guillain-Barré syndrome (GBS)}

The polyradiculitis Guillain-Barré or Guillain-Barré syndrome (GBS) is a heterogeneous autoimmune disease of the peripheral nerves. It appears after infections and vaccinations ${ }^{6}$. Lumbar CSF of patients with GBS shows a seriously increased albumin quotient, QAlb, due to the restricted outflow of $\mathrm{CSF}^{28}$ in the range of the spinal roots (Figure 3). Any humoral or cellular immune response in CSF contradicts this diagnosis, except in a very early phase of the disease with increased cell counts up to 50 cells/ $\mu$ l, but a still-low albumin quotient, QAlb ${ }^{10}$.

The analysis of antibodies in the blood of GBS patients ${ }^{8}$ resulted in interesting information about the immune system.

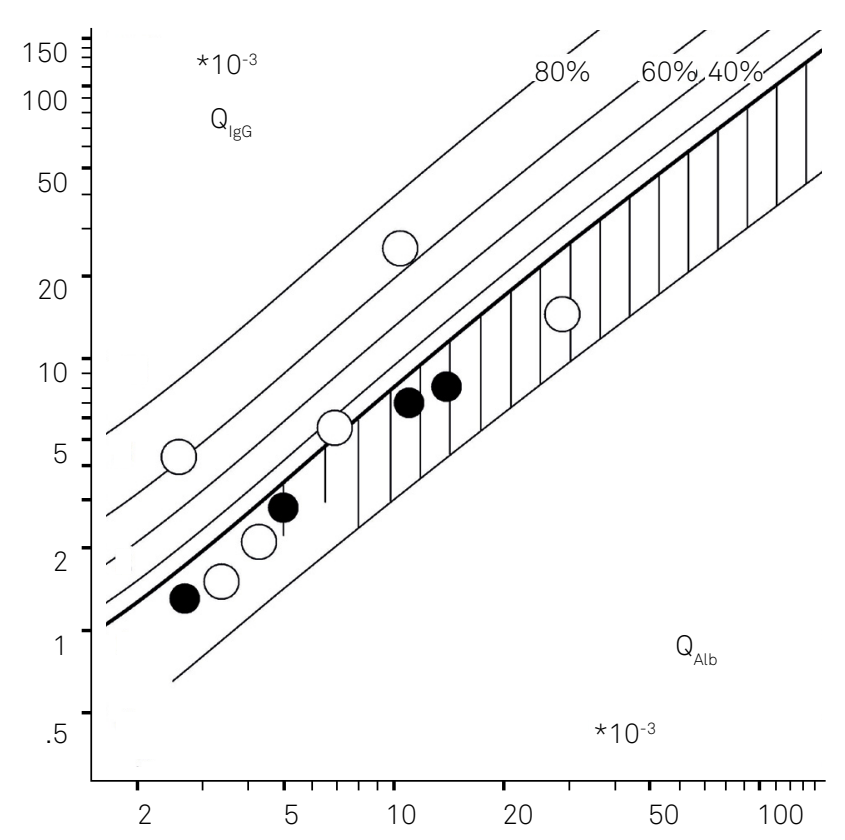

Figure 2. IgG pattern of neurolupus patients $(n=10)$ in a Reibergram ${ }^{10}$ for IgG. Six patients (open circles) had a polyspecific antibody response (Table 2). Four (40\%) patients had an age-related increased albumin quotient, QAlb, i.e. a decreased CSF flow rate ${ }^{28}$. 
Table 2. Polyspecific immune response (MRZ reaction) in the brains of patients with neurolupus? The same patients as in Figure 2.

\begin{tabular}{|c|c|c|c|c|c|c|c|c|c|}
\hline \multirow{2}{*}{ Variable } & \multirow{2}{*}{$\frac{\mathrm{CC}}{\mathrm{C} / \mu \mathrm{L}}$} & \multirow{2}{*}{$\begin{array}{l}\text { QAlb } \\
\times 10^{-3}\end{array}$} & \multirow{2}{*}{$\frac{\text { QIgG }}{x 10^{-3}}$} & \multirow{2}{*}{ OCB } & \multicolumn{5}{|c|}{ Antibody Index, Al } \\
\hline & & & & & $M$ & $\mathrm{R}$ & Z & $\mathrm{H}$ & dsDNA. \\
\hline 1 & nd & 3.0 & 1.4 & neg & 0.9 & - & 1,1 & 1.2 & 0.8 \\
\hline 2 & 3 & 2.6 & 4.3 & $\mathrm{~T} 2$ & 3.4 & 1.6 & 5,7 & nd & 0.7 \\
\hline 3 & 11 & 10.4 & 25.1 & $\mathrm{~T} 2$ & 1.5 & 5.2 & 6,9 & nd & 1.8 \\
\hline 4 & 2 & 28.7 & 14.4 & neg & 0.9 & 0.8 & 1,6 & 1.4 & 0.6 \\
\hline 5 & 4 & 13.4 & 7.7 & neg & 1.1 & 1.1 & 1 & 1.1 & 0.8 \\
\hline 6 & 9 & 12.9 & 7.5 & neg & 1.1 & 1.1 & 1 & 1.1 & 0.8 \\
\hline 7 & 2 & 3.4 & 1.5 & neg & 1.3 & 1.1 & 1,2 & 3.5 & 1.0 \\
\hline 8 & nd & 6.9 & 5.5 & T4 & 1.2 & 1.0 & 1,1 & 0.8 & 1.9 \\
\hline 9 & 1 & 4.3 & 2.1 & neg & 0.9 & 1.0 & 0,9 & 1.0 & 1.1 \\
\hline 10 & 3 & 4.3 & 2.1 & $\mathrm{~T} 2$ & 6.0 & 1.8 & 1,8 & 1.3 & 1.0 \\
\hline
\end{tabular}

CC: cell count; QAlb: albumin concentration quotient; QIgG: immunoglobulin concentration quotient; OCB: oligoclonal bands; M: measles; R: rubella; Z: varicella zoster; $\mathrm{H}$ : herpes virus; dsDNA: double-stranded DNA.

Among a large available set of antibody assays in Jim Peter's Specialty Laboratory, Santa Monica, California, the authors found a varying combination of antibodies with increased titers in blood of 56 GBS patients. Table 3 summarizes the interpretation of their results for IgG class $(\mathrm{n}=19)$ and IgM class $(\mathrm{n}=3$ ) antibody titers (total $\mathrm{n}=22$ ) of the 19 different selected infectious microbes ${ }^{8}$. In the individual blood sample between 0 and 15 different antibody species (out of 22 species analyzed) had simultaneously-increased titers. The distribution of the 56 patients over the number of simultaneouslyincreased titers is shown in Figure 4. The data are fitted with a Gaussian error function. In spite of this rough evaluation, due to the small number of patients in each group (Table 3 ), we can see that in this combination of 22 arbitrary antibody species, the median number of simultaneously-synthesizing B cell clones was about five (at the maximal point of the Gaussian distribution curve). If we suggested a connectivity ${ }^{30}$ between the synthesizing B cells, we could interpret this figure as showing a median connectivity of about five antibodysynthesizing B cell clones in the individual patient (maximal connectivity of $15 / 22$ antibody specificities). For the group of autoantibodies $(\mathrm{n}=18)$ also investigated in this study ${ }^{8}, 11 \%$ of the patient samples had a simultaneous increase of more than five structurally different autoantibodies ${ }^{8}$.

From these data we have to conclude that the polyspecific antibody response is a basic, general property of the immune system, and not restricted to the brain.

\section{A general methodological remark}

The better recognition of the polyspecific nature of the immune response in CSF compared to blood is mainly due to the higher biological sensitivity in CSF: a newly-synthesized fraction in the brain is easier to detect in CSF on top of a relatively low total IgG concentration compared to a new fraction in blood with a mean 500-fold higher total IgG concentration. Rare cases with intense oligoclonal IgG bands after a fresh infection in the blood (subsequently also seen in the CSF) are reported as type 3 and 4 in the interpretation of the isoelectric focusing results ${ }^{11,26}$.
Table 3. Frequencies of simultaneously-increased antibody titers in the blood of patients with a Guillain-Barré

polyradiculitis. These data summarize the results from

Table 4 in Terryberry et al. ${ }^{8}$, for IgG and IgM class antibodies $(n=22)$ against 19 different infectious microbes: Influenza A/B, S. pneumoniae, cytomegalovirus, human herpes virus-6, adenovirus, varicella zoster virus, mumps, herpes simplex virus 1/2, etc. See Figure 4 for interpretation.

\begin{tabular}{cc}
\hline $\begin{array}{c}\text { Number of antibody species } \\
\text { with increased titers in blood }\end{array}$ & $\begin{array}{c}\text { Frequencies in the total group } \\
(\mathrm{n}=56)\end{array}$ \\
\hline 1 & 9 \\
$2-4$ & 10 \\
$5-7$ & 10 \\
$8-10$ & 11 \\
$11-13$ & 4 \\
$14-16$ & 2 \\
$17-22$ & 0 \\
\hline
\end{tabular}

\section{NORMAL ANTIBODY DYNAMICS IN BLOOD}

The dynamics of individual antibodies in the blood of patients without an inflammatory process ${ }^{31}$ are shown in Figure 5 by the day-to-day concentration variations. The samples are from patients in an intensive care unit with clinically-indicated daily blood sampling to detect possible nosocomial infections. All titers of the antibodies investigated were normal, i.e. below the clinically-defined cut off value. All samples were analyzed together in the same analytical run (microtiter plates) to avoid a bias by analytical day-to-day imprecisions (intra-assay imprecision $\mathrm{CV}=3.5 \%)$. For the comparison, the measured concentrations were normalized for the first value $=1$. In each sample the concentrations of hemoglobin, albumin and total IgG, IgA and IgM in the blood were controlled to make sure that the day-to-day variation was not an artefact of intensive care conditions ${ }^{31}$. Figure 5 shows the day-to-day concentration variation of individual antibodies in the blood of two different patients. In both cases the correlation between measles and rubella antibody 

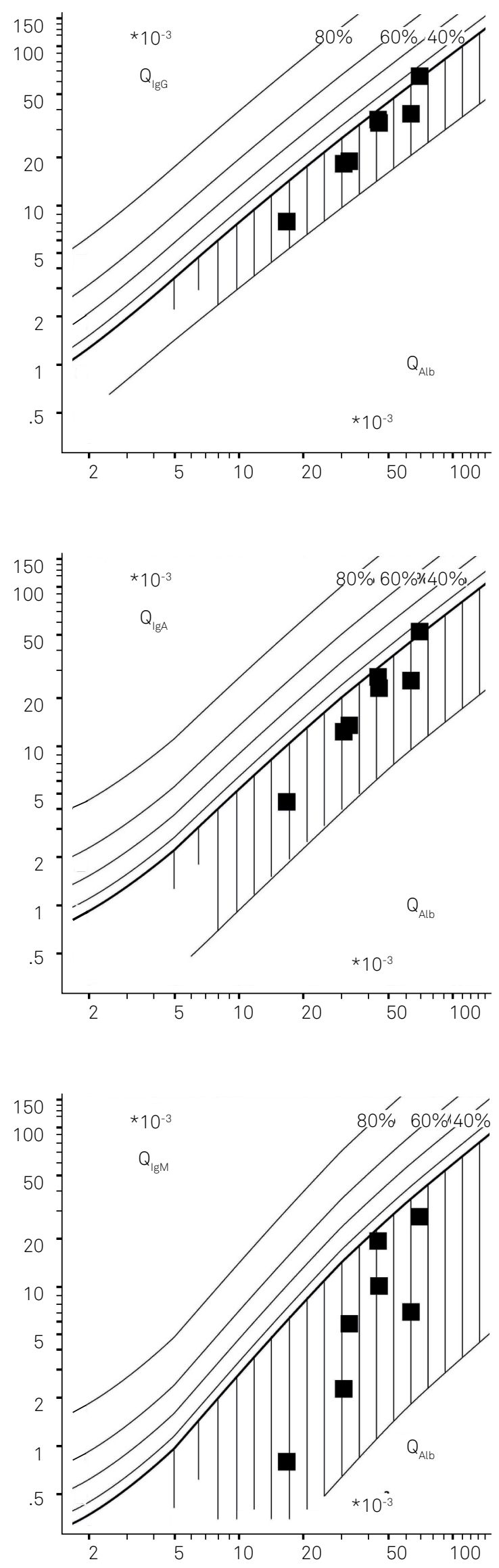

Figure 3. Patients with a Guillain-Barré polyradiculitis (GBS). Protein data in Reibergrams ${ }^{10}$. Data were analyzed in the neurochemistry laboratory, University Goettingen.

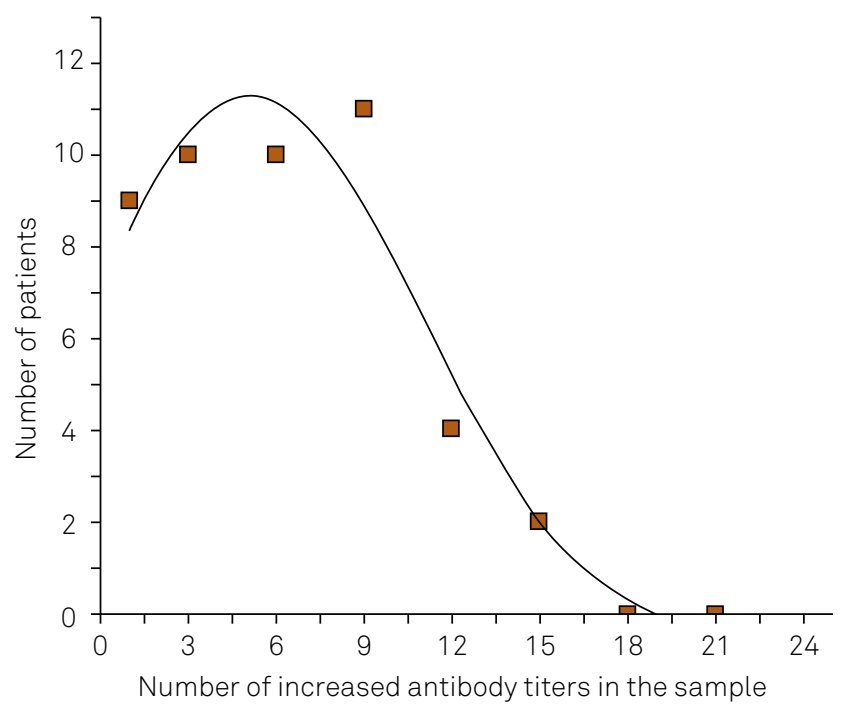

Figure 4. Frequency of Guillain-Barré (GBS) patients (total $n=56$, Table 3 ) with the number of simultaneously-increased antibody titers in blood (total $n=22$ antibody species analyzed $)^{8}$. The fit with a Gaussian function shows a mean connectivity of five antibody species out of $\operatorname{lgG}^{19}$ and $\operatorname{lgM}^{3}$ class antibodies against 19 infectious microbes.

concentrations are obviously tighter than with ds-DNA autoantibodies (upper diagram) or mumps antibodies (lower diagram). The maximal variation around a mean value is $\pm 20 \%$.

For comparison: in a nosocomial infection with reactivation of the herpes simplex virus, the HSV antibody concentration steadily increased seven-fold in five days, without remarkable variations in one case, and in another case, the increase was 40 -fold combined with an 11-fold increase of varicella-zoster virus antibody concentrations $^{31}$. In both cases, the correspondingly increased titers in blood were recognizable.

These time series with a sequence of daily concentration values measured in humans are more relevant for an interpretation than the early data from mice with a seven day interval ${ }^{32}$. The set of data $(<70-80$ uninterrupted serial time points) was too small for a reliable determination of the fractal dimension of the time series ${ }^{33,34}$. But the combined analysis of several time series according to the power law in double logarithmic diagrams allowed the exclusion of a statistical variation like a Gaussian error function $^{4,35,36}$. This allows the conclusion that the time series of antibody concentrations in blood are a deterministic chaotic variation, different from noise. This confirms the earlier suggestions ${ }^{32}$ that the cause of the variation is a regulatory process i.e., due to an algorithm of an immune network.

The intrathecal polyspecific antibody synthesis, like the polyspecific antibody activation in GBS, is a consequence of the immune network function with a natural variation of antibody concentrations in blood. 

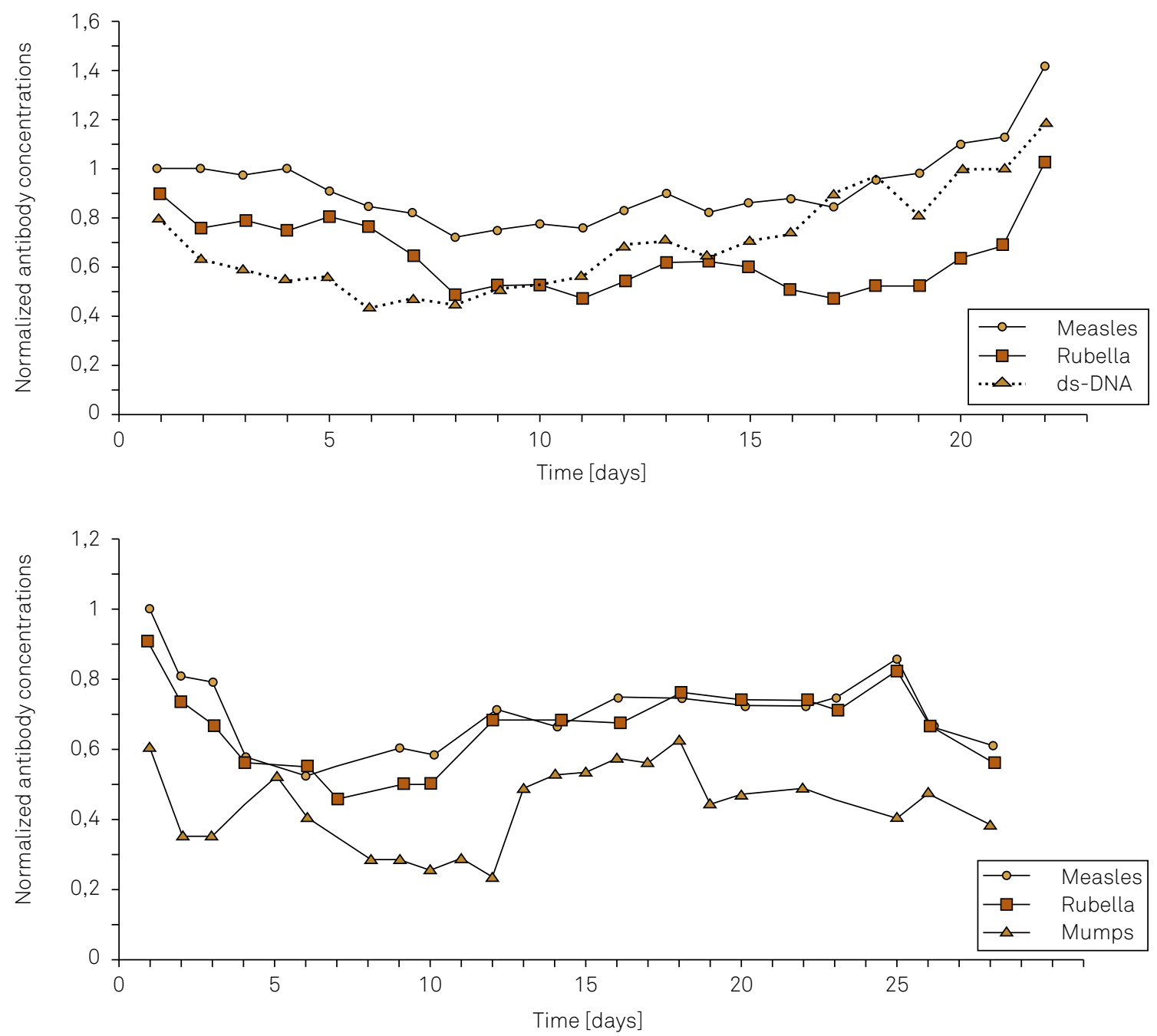

Figure 5. Antibody dynamics in blood of patients with a noninflammatory disease (stroke) in the neurological intensive care unit. Data from the thesis of S. Heitmann ${ }^{31}$. The initial decrease is due to the catabolic metabolism in the first days in intensive care and the later increases of immunoglobulins (IgG) and antibodies are due to the frequent nosocomial infection at days 5-7. A reactivation of an antigen has a much higher (>10-fold) response than the variation shown in these figures. The sampling conditions are controlled by haematocrit, albumin IgG, IgA, IgM in the samples to exclude modifications by the patient's clinical conditions ${ }^{31}$.The values are measured in the same analytical run and concentrations of the individual antibody species are normalized for the first analytical value as $C=1$. For better visibility of correlations, two curves are shifted down the Y axis in parallel. In both cases the measles and rubella antibody concentration variations are more strongly correlated, different from dsDNA autoantibodies or mumps antibodies.

\section{DISCUSSION}

\section{Natural dynamics of the immune system}

A life-long synthesis of a specific antibody by B lymphocytes in the absence of the antigen has not been easy to explain by the old clonal selection principles ${ }^{37}$. The shorter lifetime of the B cells with a daily renewal of about $20-25 \%^{12}$ required the understanding of the anti-idiotype network ${ }^{32,38}$ and the polyclonal activation of memory B cells ${ }^{39}$ to explain the maintenance of the serological memory.

The basic concepts of the immune network structure had been described about 30 years ago ${ }^{12,30,38,39,40}$. The GBS data (Table 3 and Figure 4) describe the connectivity between antibodies or B cell clones ${ }^{32}$, and the different connectivity ${ }^{8}$ from patient to patient describes the individually different network depth of the individual specific antibody or autoantibody (the number of B cell/antibody species involved in the activation cycle ${ }^{12}$ ). The nonlinear variation of the antibody concentrations provides an example for the nonlinear dynamics in the immune network.

The work of Terryberry et al., which contributed to this understanding, also represents an example of the enduring struggle with a network thinking ${ }^{12,40}$, as the authors favoured a causative interpretation ${ }^{6}$ based on clonal selection principles.

\section{Locally different MRZ patterns in the brain of MS patients: an explanation}

The observation that the MRZ pattern in chronic inflammation in the eye of an individual MS patient with a uveitis intermedia or periphlebitis retinae is different from the MRZ pattern in CSF (10/12 cases) ${ }^{14}$ and blood ${ }^{13}$, now has a rational explanation. 
Due to the continuous development and changes of antibody network depth, the MRZ pattern in blood changes without the intrathecal MRZ pattern, as B cells have no corresponding connectivity in the brain. Therefore, the actual B cell clone population in blood at the time of CSF puncture does not mirror the blood pattern at time of the start of the disease or the inflammation in the eye, which may have happened years after the general start of the disease in the brain ${ }^{1}$.

In spite of this possible correlation with the MRZ pattern in blood at time of the new bout in MS, the specificity of the immigrating B cells remains inter-individually a statistically arbitrary process as supported by many arguments (e.g. with Figure 1), but it does not offer a reason for the persistence of the intrathecal B cell clones and the particularly high frequency of the MRZ species.

\section{Causation in chronic diseases}

With the described network view on intrathecal antibody and autoantibody synthesis in MS and autoimmune diseases with involvement of the brain, we cannot pretend that this is not changing our general view on chronic diseases. We obviously have to discriminate between an acute disease with long-lasting complications and an essentially chronic disease. There is a discontinuity between an infection or vaccination and the recognition of an autoimmune disease or multisymptom illnesses of a few weeks to two months ${ }^{3,4,5,6}$ after the initiating event. In MS, as well, there is no development such as starting with an acute demyelinating meningoencephalitis and slowly becoming an $\mathrm{MS}^{19,25}$. The youngest patient, investigated at age of five years ${ }^{25}$, already had the complete set of immune reactions, like a complete MRZ antibody reaction ${ }^{25}$. A larger fraction of total MRZ at an older age ${ }^{25}$ is just a consequence of the larger total intrathecal $\operatorname{IgG}^{9}$ as a statistical event (Figure 1). The post-puberty frequencies of total MRZ antibodies are also not higher than the prepuberty frequen$\operatorname{cies}^{25}$. This type of chronic disease has a 'sudden' start.

There is the well-known example of sudden hypertension in women on contraceptive hormone treatment. Stopping the hormonal treatment does not reverse the high blood pressure. This is not a dose-effect relationship. The complex system for regulation of blood pressure has switched to a new attractor, the disease is a stable state $e^{4,41,42,43,44}$. The usual medical treatment suppresses only the symptoms but does not change the attractor ${ }^{36}$.

There are many more examples described ${ }^{41,42}$, which started with the recognition of the glucose oscillation ${ }^{43}$ as a nonlinear complex system.

The complex system approaches ${ }^{44,45}$ offer a new causation for the development of chronic diseases, which can end the useless search for a causative molecule, agent or antigen ${ }^{2}$. There may be any trigger (infection or vaccination) that facilitates the phase transition between the healthy state and the pathological stable state $e^{4,44}$, as in case of a catalyst that is not a traceable part of the system. The nature of this change (due to amplified local metabolic fluctuations ${ }^{43}$ ) also allows the possibility of a spontaneous change to a pathological state of lower complexity ${ }^{41}$ without any external influence ${ }^{4}$.

The pathological stable state is just the other side of the coin in adaptive biological systems.

\section{Therapy of chronic diseases}

The different view on the pathomechanisms of chronic diseases as a stable state of a pathological regulation must also have different therapeutic approaches; in particular, to replace unsatisfying pure treatments of symptoms. Examples of the development of causal therapies in chronic diseases have been reported ${ }^{4,45,46}$, but we need further research for suitable applications, different from the linear symptom-oriented solutions of the industrial-medical complex ${ }^{47,48}$ with divergent interests. The blockage of the $\mathrm{B}$ cell migration into the brain is a temporary commercial solution, which shows that the B cells are involved in the pathophysiology but, again, this offers no causative therapy.

\section{ACKNOWLEDGEMENT}

I appreciate the great efforts of the doctoral students, Stefan Ungefehr, Susanne Heitmann, Klaus Hirzel, Meike Albrecht and Christian Jacobi, who have contributed the cited data for the view on the polyspecific antibodies in chronic diseases. My particular thanks go to my friend Peter Lange who, over so many years, provided the quality of a most sensitive antibody analysis in the Neurochemistry Laboratory in Goettingen.

\section{References}

Reiber H, Kruse-Sauter H, Quentin CD. Antibody patterns vary arbitrarily between cerebrospinal fluid and aqueous humor of the individual multiple sclerosis patient: specificity-independent pathological B cell function. J Neuroimmunol. 2015;278:247-54. https://doi.org/10.1016/j.jneuroim.2014.11.013

Vaughan K, Peters B, O'Connor KC, Martin R, Sette A. A molecular view of multiple sclerosis and experimental autoimmune encephalitis: what can we learn from the epitope data? J Neuroimmunol. 2014;267(1-2):73-85. https://doi.org/10.1016/j.jneuroim.2013.12.009
3. Nielsen PR, Kragstrup TW, Deleuran BW, Benros ME. Infections as risk factor for autoimmune diseases: a nationwide study. J Autoimmun. 2016;74:176-81. https://doi.org/10.1016/j.jaut.2016.05.013

4. Reiber $\mathrm{H}$. Chronic diseases with delayed onset after vaccinations and infections: a complex systems approach to pathology and therapy. J Arch Milit Med. 2017; 5(2) e 12285, in press.

5. Hotopf M, David A, Hull L, Ismail K, Unwin C, Wessely S. Role of vaccinations as risk factors for ill health in veterans of the Gulf war: cross sectional study. BMJ. 2000;320(7246):1363-7.https://doi.org/10.1136/bmj.320.7246.1363 
6. Shoenfeld Y, Aron-Maor A. Vaccination and autoimmunity: 'vaccinosis': a dangereous liaison? J Autoimmun. 2000;14(1):1-10. https://doi.org/10.1006/jaut.1999.0346

7. Graef IT, Henze T, Reiber H. Polyspezifische Immunreaktion im ZNS bei Autoimmun-Erkrankungen mit ZNS Beteiligung. Z Ärztl Fortbild. 1994;88:587-91.

8. Terryberry J, Sutjita M, Shoenfeld Y, Gilburd B, Tanne D, Lorber M et al. Myelin- and microbe-specific antibodies in Guillain-Barré syndrome. J Clin Lab Anal. 1995;9(5):308-19. https://doi.org/10.1002/jcla.1860090506

9. Reiber H, Ungefehr S, Jacobi C. The intrathecal, polyspecific and oligoclonal immune response in multiple sclerosis. Mult Scler. 1998;4(3):111-7. https://doi.org/10.1177/135245859800400304

10. Reiber H. Cerebrospinal fluid data compilation and knowledge-based interpretation of bacterial, viral, parasitic, oncological, chronic inflammatory and demyelinating diseases: diagnostic patterns not to be missed in neurology and psychiatry. Arq Neuropsiquiatr. 2016;74(4):337-50. https://doi.org/10.1590/0004-282X20160044

11. Reiber $\mathrm{H}$. Knowledge-base for interpretation of cerebrospinal fluid data patterns: essentials in neurology and psychiatry. Arq Neuropsiquiatr. 2016;74(6):501-12. https://doi.org/10.1590/0004-282×20160066

12. Varela FJ, Coutinho A. Second generation immune networks. Immunol Today. 1991;12(5):159-66. https://doi.org/10.1016/S0167-5699(05)80046-5

13. Jacobi C, Lange P, Reiber H. Quantitation of intrathecal antibodies in cerebrospinal fluid of subacute sclerosing panencephalitis, herpes simplex encephalitis and multiple sclerosis: discrimination between microorganism-driven and polyspecific immune response. J Neuroimmunol. 2007;187(1-2):139-46. https://doi.org/10.1016/j.jneuroim.2007.04.002

14. Quentin CD, Reiber H. Fuchs' heterochromic cyclitis: rubella virus antibodies and genome in aqueous humor. Am J Ophthalmol. 2004;138(1):46-54. https://doi.org/10.1016/j.ajo.2004.02.055

15. Sindic CJ, Monteyne P, Laterre EC. The intrathecal synthesis of virusspecific oligoclonal IgG in MS. J Neuroimmunol. 1994;54(1-2):75-80. https://doi.org/10.1016/0165-5728(94)90233-X

16. Felgenhauer K, Schädlich H, Nekic M, Ackermann R. Cerebrospinal fluid virus antibodies: a diagnostic indicator for multiple sclerosis. J Neurol Sci. 1985;71(2-3):292-9. https://doi.org/10.1016/0022-510X(85)90067-X

17. Jarius S, Franciotta D, Bergamaschi R, Rauer S, Wandinger KP, Petereit HF et al. Polyspecific, antiviral immune response distinguishes multiple sclerosis and neuromyelitis optica. J Neurol Neurosurg Psychiatry. 2008;79(10):1134-6. https://doi.org/10.1136/jnnp.2007.133330

18. Jarius S, Eichhorn P, Jacobi C, Wildemann B, Wick M, Voltz R. The intrathecal, polyspecific antiviral immune response: specific for MS or a general marker of CNS autoimmunity? J Neurol Sci. 2009;280(1-2):98-100. https://doi.org/10.1016/j.jns.2008.08.002

19. Hottenrott T, Dersch R, Berger B, Rauer S, Eckenweiler M, Huzly D et al. The intrathecal, polyspecific antiviral immune response in neurosarcoidosis, acute disseminated encephalomyelitis and autoimmune encephalitis compared to multiple sclerosis in a tertiary hospital cohort. Fluids Barriers CNS. 2015;12(1):27. https://doi.org/10.1186/s12987-015-0024-8

20. Conrad AJ, Chiang EY, Andeen LE, Avolio C, Walker SM, Baumhefner RW et al. Quantitation of intrathecal measles virus IgG antibody synthesis rate: subacute sclerosing panencephalitis and multiple sclerosis. J Neuroimmunol. 1994;54(1-2):99-108. https://doi.org/10.1016/0165-5728(94)90236-4

21. Robinson-Agramonte M, Reiber H, Cabrera-Gomez JA, Galvizu R. Intrathecal polyspecific immune response to neurotropic viruses in multiple sclerosis: a comparative report from Cuban patients. Acta Neurol Scand. 2007;115(5):312-8. https://doi.org/10.1111/j.1600-0404.2006.00755.x
22. Hirzel K. Avidität antiviraler Antikörper in Liquor cerebrospinalis und Serum bei akuten und chronischen Entzündungen des Zentralnervensystems [Diplomarbeit]. Goettingen: Biologische Fakultät der Universität Goettingen; 1997.

23. Gharavi AE, Reiber H. Affinity and avidity of autoantibodies. In: Peter JB, Shoenfeld Y, editors. Autoantibodies. Amsterdam: Elsevier; 1996. p.13-23

24. Luxton RW, Thompson EJ. Affinity distributions of antigen-specific IgG in patients with multiple sclerosis and in patients with viral encephalitis. J Immunol Methods. 1990;131(2):277-82. https://doi.org/10.1016/0022-1759(90)90199-6

25. Reiber H, Teut M, Pohl D, Rostasy KM, Hanefeld F. Paediatric and adult multiple sclerosis: age-related differences and time course of the neuroimmunological response in cerebrospinal fluid. Mult Scler. 2009;15(12):1466-80. https://doi.org/10.1177/1352458509348418

26. Reiber H, Peter JB. Cerebrospinal fluid analysis: disease-related data patterns and evaluation programs. J Neurol Sci. 2001;184(2):101-22. https://doi.org/10.1016/S0022-510X(00)00501-3

27. Reiber H, Ressel CB, Spreer A. Diagnosis of neuroborreliosis: improved knowledge base for qualified antibody analysis and cerebrospinal fluid data pattern related interpretations. Neurol Psychiatry Brain Res. 2013;19(4):159-69.

https://doi.org/10.1016/j.npbr.2013.10.004

28. Reiber H. Flow rate of cerebrospinal fluid (CSF): a concept common to normal blood-CSF barrier function and to dysfunction in neurological diseases. J Neurol Sci. 1994;122(2):189-203. https://doi.org/10.1016/0022-510X(94)90298-4

29. Bechter K, Reiber H, Herzog S, Fuchs D, Tumani H, Maxeiner HG. Cerebrospinal fluid analysis in affective and schizophrenic spectrum disorders: identification of subgroups with immune responses and blood-CSF barrier dysfunction. J Psychiatric Res. 2010;44(5):321-30. https://doi.org/10.1016/j.jpsychires.2009.08.008

30. Stewart J, Varela FJ. Exploring the meaning of connectivity in the immune network. Immunol Rev. 1989;110(1):37-61. https://doi.org/10.1111/j.1600-065X.1989.tb00026.x

31. Heitmann S. Dynamik der polyspezifischen Immunreaktion bei nosokomialen Infektionen [Dissertation]. Goettingen: Med Fakultät der Georg August Universität Goettingen; 2002 .

32. Lundkvist I, Coutinho A, Varela F, Holmberg D. Evidence for a functional idiotypic network among natural antibodies in normal mice. Proc Natl Acad Sci. 1989;86(13):5074-8. https://doi.org/10.1073/pnas.86.13.5074

33. Pincus S. Approximate entropy (ApEn) as a complexity measure. Chaos. 1995;5(1):110-7. https://doi.org/10.1063/1.166092

34. Cysarz D, Bettermann H, Leeuwen P. Entropies of short binary sequences in heart period dynamics. Am J Physiol Heart Circ Physiol. 2000;278(6):H2163-72.

35. Mandelbrot BB. The fractal geometry of nature. New York: WH Freeman; 1982.

36. Reiber H. Die Komplexität biologischer Gestalt als zeitunabhängiges Konstrukt im Zustands-Raum. Zum naturwissenschaftlichen Umgang mit Qualitäten. In: Zeilinger D, editor. VorSchein, Jahrbuch der Ernst-Bloch-Assoziation, Nürnberg:Antogo; 2007. p. 39-61.

37. Rajewsk K. Clonal selection and learning in the antibody system. Nature. 1996;381(6585):751-8. https://doi.org/10.1038/381751a0

38. Perelson AS. Immune network theory. Immunol Rev. 1989;110(1):5-36. https://doi.org/10.1111/j.1600-065X.1989.tb00025.x

39. Bernasconi NL, Traggiai E, Lanzavecchia A. Maintenance of serological memory by polyclonal activation of human memory B cells. Science. 2002;298(5601):2199-202. https://doi.org/10.1126/science.1076071

40. Coutinho A. The network theory:21 years later. Scand J Immunol. 1995;42(1):3-8. https://doi.org/10.1111/j.1365-3083.1995.tb03619.x 
41. Goldberger AL. Is the normal heartbeat chaotic or homeostatic? News Physiol Sci. 1991;6:87-91.

42. Gerok W. Ordnung und Chaos als Elemente von Gesundheit und Krankheit. In:Verhandlungen d. Ges. Deutsch. Naturforscher und Ärzte. Editor. Ordnung und Chaos in der unbelebten und belebten Natur. Stuttgart: Wissenschaftl.Verlagsges; 1988. p. 19-41.

43. Hess B, Markus M. Chemische Uhren. In: Dress A, Hendrichs H, Küppers G, editors. Selbstorganisation: Die Entstehung von Ordnung in Natur und Gesellschaft. München: Piper; 1986. S.61

44. Reiber H. Epigenesis and epigenetics - understanding chronic diseases as a selforganizing stable phenotype. Neurol Psychiatry Brain Res. 2012;18(2):79-81. https://doi.org/10.1016/j.npbr.2012.02.001
45. Mayer H., Zaenker KS, Heiden U.A basic mathematical model of the immune response. Chaos. 1995;5(1):155-61. https://doi.org/10.1063/1.166098

46. Prange $\mathrm{H}$, Wismann $\mathrm{H}$. Intrathecal use of interferon in encephalitis. New Engl. J Med. 1981;305(21):1283-4. Https://doi.org/10.1056/NEJM198111193052113

47. Jupiter J, Burke D. Scott's parabola and the rise of the medical-industrial complex. Hand (NY). 2013;8(3):249-52. https://doi.org/10.1007/s1152-013-9526-5

48. Reiber H. [Cerebrospinal fluid diagnostics in Germany since 1950: develepments in the GDR and FRG in the context of society and science]. Nervenarzt 2016;87(12):1261-70. German. https://doi.org/10.1007/s00115-016-0241-7 